\title{
Discrimination, policies, and sexual rights in Brazil
}

\author{
Discriminação, políticas e direitos \\ sexuais no Brasil
}

Sergio Carrara 1

\footnotetext{
1 Instituto de Medicina Social, Universidade do Estado do Rio de Janeiro, Rio de Janeiro, Brasil.

Correspondence

S. Carrara

Instituto de Medicina Social, Universidade do Estado do Rio de Janeiro.

Rua São Francisco Xavier 524, 6o andar, bloco $E$,

Rio de Janeiro, RJ 20550-013, Brasil.

carrara@ims.uerj.br
}

\begin{abstract}
This article focuses on a politics arena that has been articulated through the impact of ideals of sexual rights on Brazilian sexual politics, namely the affirmation of "LGBT rights". These rights have been constructed both through attempts to extend civil and social rights to the LGBT population that were previously restricted to heterosexuals, and by the enactment of provisions directly banning homophobic discrimination and violence. The focus will be on some of the principal social actors in this process, especially those situated in the three branches of government, since the most decisive clashes are now being waged at this level. Without intending to offer an exhaustive description of what has occurred in the Brazilian courts, Congress, and Administration, we point to the complexity of a situation which shows numerous innovations and breaks in its different dimensions, while simultaneously revealing contradictions, gaps, and ambiguities.
\end{abstract}

Prejudice; Homosexuality; Politics
The basic ideas addressed in this article are linked to the thinking developed in a broader line of research - Sexual Knowledge and Policies in Brazil-launched in the 1990s, with a survey and analysis of historical data on proposals for social intervention for control or eradication of sexually transmitted diseases in Brazil 1. In keeping with the propositions by Weeks 2, the concept of sexual politics was incorporated into the reflections to define all types of interventions (laws, health campaigns, educational programs, or legal rulings) directly by the state or under its aegis, and with two objectives: (i) to regulate erotic/ sexual practices and expressions of sexuality (ii) to manage certain phenomena pertaining to these practices, like reproduction and sexually transmitted diseases. The idea that to manage, regulate, administer, or control are prime modes of action by state power derives clearly from the work of Michel Foucault 3,4 and runs against the more traditional views that perceive such actions as essentially limiting and unproductive, non-propositional, and uncreative. Expressions like manage or regulate thus reveal a concept of power that is creative or institutive even when it limits or represses.

At least in terms of its scope, the concept of sexual politics encompasses multiple dimensions of social management of the erotic and the sexual. On the one hand, revolving around the very definition of sex, sexuality, and eroticism, it relates to a politics of representation, producing 
- in a given social configuration - that which can be known and consequently said, seen, heard, or even fantasized about "sex". Meanwhile, sexual politics is constituted as a politics of sexual or erotic relations, pertaining, among other things, to the public regulation of marriages, prostitution, sexual crimes, age of consent, etc.

Although sexual politics initially developed in socio-political spaces defined according to the borders of national states and were fundamental for nation-building processes, they have been forged increasingly at the international level, implemented through commitments assumed between states, with the mediation of agencies such as those in the United Nations system ${ }^{5}$. As the result of confrontation or coalition between different social actors over the course of a given period of time, the nature of such policies is complex, incorporating distinct interests and simultaneously reflecting highly diverse representations and social values: scientific ideas (especially biomedical theories), religious beliefs, moral values, legal principles, political positions etc. Thus, it is not surprising to find inconsistencies and contradictions within the same sexual politics, even when the analysis may identify predominant meanings or lines of force.

In general, through the incorporation of the concept of sexual politics, the attempt has been to design what one could call styles of moral regulation, i.e., sets of techniques for production of subjects by which persons are provided with a certain self-concept and encouraged to establish a unique relationship with their own body. In Brazil, various authors, particularly Duarte 6, have focused on the importance of sexuality (or the supposed style of moral regulation in its device) for social and political processes of constitution of modern subjects, with the imperatives of reflexivity, self-control, and political and social engagement (awareness of one's rights and duties).

One can argue that the concept of sexual politics as developed here is none other than the more formalized and visible part of the device of sexuality, as analyzed by Michel Foucault 3; or even that it is the very concept of device of sexuality itself, "operationalized" to be applied in more precise and demarcated social and historical contexts. However, the concept, as explored here, does not assume the incorporation of the entire Foucaultian analytical apparatus; in particular, it does not assume that under or within a given sexual politics there is a single sense that would lead (through discipline) to the production of docile bodies and a manageable population. Thus, it allows exploring the coexistence, in a given social configuration, of distinct and sometimes con- tradictory styles of moral regulation. At any rate, the important issue is to highlight that styles of moral regulation encompassed in a given sexual politics circumscribe a set of subjects who, given their practices and desires, are systematically discriminated against or marginalized. As in other countries, the sexual politics developed in Brazil since the late 19th century has the following as its problematic "others": homosexuals, prostitutes, men and women that are considered sexually promiscuous, carriers of sexually transmitted diseases, etc. It is precisely the statute of these "others" that has been challenged with the emergence of the discussion concerning sexual rights.

This article focuses on one of the arenas that have been articulated based on the impact of human rights ideals on Brazil's sexual politics, i.e., that of the struggle for so-called "LGBT right" or rights pertaining to what has come to be called "sexual diversity". Such "LGBT rights", which often have nothing to do directly with sexuality (i.e., pension issues, adoption, freedom to come and go in public places, or name and sex changes on birth certificates), have come to be viewed as sexual rights, given that, historically speaking, the social and political processes of stigmatization and discrimination that deprive LGBT persons of such rights have involved certain values pertaining to sexuality. In other words, as currently constructed in Brazil, sexual rights refer to legal provisions pertaining either to sexuality or to social groups whose identities were shaped on specific forms of desires and sexual practices.

Men and women who break with social conventions of gender and sexuality are particularly exposed to situations of violence and discrimination. While homosexuality is not a crime in Brazil, situations involving violence and discrimination against gays, lesbians, travestis, and transsexuals are numerous and have been the focus of action by the LGBT movement since its beginning.

Although such concepts as violence against homosexuals, homophobic violence and discrimination, and homophobia have circulated relatively recently, they have been used by activists and researchers in the attempt to understand the phenomenon's specificity, as the target of growing concern not only among activists, but also in government and the media. However, the conceptual relations between gender violence and homophobic violence have received relatively little attention thus far ${ }^{7}$. In the latter case, breaks with social conventions in sexuality (nonheterosexual practices and desires) and breaks 
with gender conventions (public manifestation of what are considered feminine behaviors by men and masculine behaviors by women) are differentially involved in the contexts of violence and discrimination.

As organizations in the LGBT movement have denounced for decades, in addition to the extreme cases involving assassinations, many other forms of violence and discrimination affect gays, lesbians, travestis, and transsexuals. Recent data on victimization produced in conjunction with the LGBT pride parades have indicated that some $60 \%$ of interviewees report having been victims of some form of discrimination or violence due to their sexuality ${ }^{8,9}$. In general, such data have pointed to the multifaceted nature of homophobic violence. In many cases, it displays the more classic characteristics of "hate crimes". The latter concept first appeared in the United States in the mid-1980s in the context of the effort to separate crimes motivated by racial, ethnic, or religious prejudice from ordinary crimes as a whole. Unlike the Brazilian legislation, which considers racism a crime, the concept of hate crime functions in the United States as an aggravating factor for crimes already included in the penal code 10 rather than as a specific crime itself. In many cases, men and women that are sufficiently "courageous" (or "careless") to display their difference in public are subjected to physical assault by anonymous aggressors; in many other cases, it occurs in the context of affectively dense social relations, involving family or friends. Thus, when the issue is homophobic violence, the "home" does not appear to serve as major protection against the anonymous violence of the "street". In addition, the experience is almost unspeakable, since the quantitative data also show that the vast majority of victims fail to report the occurrence to anyone, and particularly that they almost never file complaints through public institutions.

In addition to claiming state protection against homophobic violence in its most brutal forms (verbal and physical aggression and assassinations), the agenda of the Brazilian LGBT Movement currently includes a wide set of demands: the right to legal recognition of affectivesexual relations, joint adoption of children, free expression of sexual and/or gender orientation in public places, "sex" redesignation and name change on identification documents, and access to specific health policies. This agenda has also been promoted through a complex and multiple network of relations, in which some social actors - NGOs, government agencies, political parties, Members of Congress, judges, jurists, university research centers, market players, research fund- ing agencies, religious organizations, and professional societies - act purposely to support it, while others fight to deny or disqualify it.

LGBT rights are constructed through attempts to extend civil and social rights previously restricted to heterosexuals or by enacting provisions that directly prohibit homophobic discrimination and violence. This article focuses on only some of these actors, especially those situated in the three branches of government, where the most decisive clashes are currently waged, setting a scene which is no longer one of pure confrontation, but of huge expectations and numerous challenges.

\section{$\star \star \star$}

Brazil's 1988 Constitution 11 is important for understanding how contemporary sexual politics is developed at the state level. Formally terminating the long period of authoritarian rule launched by the military coup in 1964, the 1988 Constitution mirrors the characteristics of the democratization process that began in the late 1970s. As in other Latin American countries, the struggle to reestablish classical political rights (voting, free political expression, freedom of association, etc.) was combined with demands to promote a broader human rights agenda. This process combined not only forces from the Left, banned by the military regime, but also new political subjects who organized around gender and sexuality issues during the dictatorship years. Thus, in addition to social rights, women's reproductive rights and the rights of different sexual minorities came to the surface.

The so-called "Citizens' Constitution" mirrored the prevailing configuration of different social movements that sought to transpose to the public sphere a series of issues that were previously considered exclusive to private life. In some cases, the changes were major, like the formulation of gender equity as a Constitutional right and the legal recognition of the existence of diverse forms of families, clear reflections of the force of feminist and women's groups. Other cases, like the fact that the new Constitution failed to include "sexual orientation" and "gender identity" among the various situations of discrimination to be combated by the public powers, show how unfavorable the political context was at that time for certain groups, like those comprising what was then referred to as the Brazilian Homosexual Movement, or LGBT Movement, the current designation for a collective subject consisting of lesbians, gays, bisexuals, travestis, and transsexuals. The differences between such identities and the way they express themselves politically is part 
of a complex process that we will not discuss in detail here. Suffice it to recall that the borders between such identities are not all that clear and are in a constant process of negotiation.

Even with occasional "setbacks", the Constitution's overall structure, explicitly bound to respect for human rights and the enforcement of commitments signed in international treaties, has allowed numerous judges and courts to elaborate on its fundamental principles to guarantee certain rights in practice and to contribute to the creation of new laws ${ }^{11}$. In many cases, especially those involving pension rights, court action has opened the way for legislative changes. The principles of the 1988 Constitution also provided the basis for the Brazilian Supreme Court to recently extend the rights previously reserved to heterosexual couples to stable unions between persons of different sexes. The 1988 Constitution should thus be considered a milestone based on which sexuality and reproduction have become a legitimate arena for the exercise of rights in Brazil. From civil society's perspective, the demands for such rights are currently organized around the Constitution, and from the state's perspective, it provides the basis for generating public policies, legal instruments, and court rulings to respond to such demands.

The Federal government has been designing and implementing increasingly comprehensive public policies for the LGBT population. Initiated by previous Administrations within the fight against AIDS, state recognition and promotion of LGBT rights now extend across different ministries and secretariats, and have even been essential for the movement's organization. As a fundamental reference in this process, the creation of Brazil without Homophobia: the Program to Combat Violence and Discrimination Against GLBT and Promotion of Homosexual Citizenship, was launched by the Federal Government in May 2004 (recognizing both the specificity and the diversity of forms of violence that affect LGBT, the program was elaborated by a commission under the National Council to Combat Discrimination, with support from the Ministry of Health and participation by various activists and militant organizations, like the ABGLT). One of the Program's most significant spinoffs was the 1st National Conference of Gays, Lesbians, Bisexuals, travestis, and Transsexuals, held in Brasília in June 2008, attended by the President of Brazil. Based on the conclusions of the Conference, an Inter-Ministerial Technical Commission organized the National Plan for the Promotion of LGBT Citizenship and Human Rights, published in 2009 by the Federal Government, with actions to be developed by various ministries. The Plan's main objectives include "fighting stigma and discrimination on grounds of sexual orientation and gender identity" and implementing "public policies that contemplate actions to combat homophobia and promote citizenship and human rights".

Some of the guidelines in the program and plan have been implemented by various ministries and secretariats. Since 2005, the Ministry of Education has issued calls for projects to train teachers on issues related to "sexual orientation" and "gender identity" 12 . Meanwhile, the Special Secretariat for Human Rights has supported the creation of dozens of human rights referral centers with the objective of preventing and combating homophobic violence and discrimination, providing legal aid and psycho-social support to victims. Spread all across the country, many of these centers are being set up inside organizations from the LGBT movement and others in State and Municipal secretariats.

In the Ministry of Health, in addition to actions by the National STD-AIDS Program, important measures have been taken concerning the rights of transsexuals to undergo sex reassignment surgery and thereby succeed in changing their legal identity. Until 1997, the Federal Board of Medicine viewed sex change surgery as malpractice, subject to criminal action as "bodily injury”. Ruling $n^{\circ}$. 1.652/2002 by the Federal Board of Medicine established the conditions for such surgery to be performed, specifying, at the practical level, that it be done "in university hospitals or public hospitals that are adequate for the research", in cases of adapting the female to the male phenotype, or in public or private hospitals, regardless of the research activity, in cases of adapting the male to the female phenotype. More recently, under Ruling no. 1.707 (August 18, 2008), the Minister of Health established the "transsexualizing process" within the sphere of the Brazilian Unified National Health System (SUS). The wording of the Ruling does not deal explicitly with transsexuality as an illness or disorder, but bases its position on the Ruling by the Federal Board of Medicine, according to which "the transsexual patient" has "a permanent psychological deviation in sexual identity, including rejection of the phenotype and a tendency to selfmutilation and/or self-extermination".

Meanwhile, the Federal Executive Branch has proven relatively receptive to pressure by "organized civil society". This permeability is partially explained by the political background of the leading party in the coalition now in power (the Workers' Party) and partly also by the new public administration models that have been established through state reform, in the sense of installing 
the "minimum state", since the mid-1980s. In the field of social policies, AIDS was the first major experiment in this new type of management, which is now being extended to other areas.

In striking contrast to current trends in the Judiciary and Executive Branches, inertia and conservatism have characterized the work of Brazil's Legislative Branch, especially at the Federal level. In an attempt to reverse this situation and push for the approval of legislation like the civil union bill and the proposal for a Constitutional amendment explicitly condemning discrimination on grounds of sexual orientation, in October 2003 the Chamber of Deputies officially launched the Joint Congressional Front for Free Sexual Expression, later renamed the Congressional Front for GLBT Citizenship. Some more specific bills aim to guarantee certain rights or ban discrimination and homophobic violence.

As for violence and discrimination, discussion has focused on Bill of Law no. 122, initially submitted by Congresswoman Iara Bernardi (Workers' Party, São Paulo) in 2004, passed by the Chamber of Deputies in 2008, and currently under review in the National Senate. The bill aims to amend Law no. 7716 of 1989, which defines the crimes resulting from prejudice on grounds of race and color, thereby also altering the country's Penal Code, to include prejudice based on "sexual orientation and gender identity" among the forms of prejudice punishable by law. Discussions on the "criminalization of homophobia" have raised numerous doubts pertaining to freedom of speech. Since Law no. 7716 also typifies as a crime the act of "inducing or inciting to discrimination or prejudice", many oppose the new law on the argument that it would also apply to priests and pastors who still consider homosexuality a sin.

Viewed as a whole, the issue of LGBT sexual rights has acquired great density, testing the very democratic and secular nature of the Brazilian state, meanwhile giving rise to a crisis in the relationship between the branches of government, as witnessed in the recent clash between Members of Congress and Justices of the Supreme Court concerning stable unions between persons of the same sex, with National Deputies accusing the Court of invading their jurisdiction and Justices claiming that Congress is failing to meet its role in the consolidation of a democratic society. A similar example was the recent clash between Deputies from the Congressional "religious front" and the Executive Branch over proposals by the Ministry of Education to combat homophobia in schools.
Until recent years, the notion of "sexual rights" was much less widespread and its meanings were still obscure. Over the last decade, the notion has come to carry greater weight, linked not only to the principle of freedom, involving individuals' privacy, but also equality and the secular nature of the state. When we began to reflect on the emergence and dissemination of the notion of "sexual rights", we approached them merely as the result of the impact of the human rights perspective on sexuality. It appeared to us at the time that human rights ideals could establish the ethical parameters for the study of sexuality and (on the political level) define which sexualities could aspire to the right to citizenship. With time, we realized that reflection on sexuality from the human rights perspective, from which sexual rights are born, represents far more than this and marks a crucial break in the very history of sexuality. As the result of the dynamic relationship between multiple social actors (activists, politicsmakers, politicians, jurists, intellectuals, etc.), sexual rights can be considered a kind of symbol of a new sexual politics, with a specific morality, rationale, and regulations. We are thus experiencing a moment of transition in which new institutional and legal devices are being implemented to ban prejudices and processes of discrimination that have marked Brazilian sexual politics for more than a century.

The aim here was not to offer an exhaustive description of what has occurred in the Brazilian courts, Congress, and Administration in relation to LGBT rights, but merely to point to the complexity of a situation which shows numerous innovations and breaks in its different dimensions, while simultaneously revealing contradictions, gaps, and ambiguities. We do not know what its limits will be or how it will play out in the future, especially given the political positions that resist any change in the sense of public recognition of different expressions of sexuality and gender. Still, there is no doubt that the actions and interventions unfolding at the state level are part of a profound process of transformation of sexual morals in Brazil, with a significant impact on them. 


\section{Resumo}

Este artigo privilegia uma das arenas políticas que vêm sendo articuladas a partir da incidência do ideário dos direitos sexuais sobre a política sexual brasileira, qual seja, o processo de afirmação dos chamados “direitos LGBT". A construção desses direitos se faz, seja por meio de tentativas de estender à população LGBT direitos civis e sociais antes restritos a heterossexuais, seja por intermédio da promulgação de dispositivos que coíbam diretamente a discriminação e a violência homofóbica. Estarão em foco alguns dos principais atores sociais envolvidos nesse processo, especialmente aqueles situados nos três poderes constituídos do Estado, uma vez que é nesse plano que atualmente têm se dado os embates mais decisivos. Sem se propor a oferecer um painel exaustivo do que tem acontecido na justiça, no congresso e no governo, apontamos para a complexidade de um quadro que, revelando em suas diferentes dimensões inúmeras inovações e rupturas, não deixa de apresentar igualmente contradições, defasagens e ambiguidades.

Preconceito; Homossexualidade; Políticas

\section{References}

1. Carrara S. Tributo a Vênus: a luta contra a sífilis no Brasil da passagem do século aos anos 1940. Rio de Janeiro: Editora Fiocruz; 1996.

2. Weeks J. Sex, politics and society: the regulation of sexuality since 1800. London/New York: Longman; 1989.

3. Foucault M. História da sexualidade I. A vontade de saber. Rio de Janeiro: Edições Graal; 1976.

4. Foucault M. Microfísica do poder. Rio de Janeiro: Edições Graal; 1979.

5. Vianna A, Lacerda P. Direitos e políticas sexuais no Brasil: o panorama atual. Rio de Janeiro: Centro de Estudos e Pesquisa em Saúde Coletiva; 2004.

6. Duarte LFD. A sexualidade nas ciências sociais: leitura crítica das convenções. In: Piscitelli A, Gregori MF, Carrara S, organizadores Sexualidade e saberes: convenções e fronteiras. Rio de Janeiro: Garamond; 2004. p. 39-80.

7. Gómez MM. Los usos jerárquicos y excluyentes de la violencia. In: Cabal L, Motta C, editores. Más allá del derecho: justicia y género en América Latina. Bogotá: Siglo Del Hombre Editores; 2006. p. 19-55.
8. Carrara S, Ramos S. Política, direitos violência e homossexualidade: pesquisa da 9a Parada do Orgulho LGBT - Rio, 2004. Rio de Janeiro: Centro de Estudos e Pesquisa em Saúde Coletiva; 2005.

9. Carrara S, Ramos S, Simões JA, Facchini R. Política, direitos, violência e homossexualidade: pesquisa da 9a Parada do Orgulho GLTB - São Paulo, 2005. Rio de Janeiro: Centro de Estudos e Pesquisa em Saúde Coletiva; 2006.

10. Jacobs JB, Potter K. Hate crimes - criminal law \& identity politics. Oxford/New York: Oxford University Press; 1998.

11. Carrara S, Vianna AR. Os direitos sexuais e reprodutivos no Brasil a partir da "Constituição Cidadã". In: Oliven RG, Ridenti M, Brandão GM, organizadores. A Constituição de 1988 na vida brasileira. São Paulo: Editora Hucitec; 2008. p. 334-59.

12. Secretaria de Educação Continuada e Diversidade, Ministério da Educação. Cadernos SECAD 2007; (4).

Submitted on $11 / \mathrm{Jul} / 2011$

Approved on 04/Aug/2011 